\title{
PERBANDINGAN UJI RESISTENSI BAKTERI STAPHYLOCOCCUS AUREUS TERHADAP OBAT ANTIBIOTIK AMPISILIN DAN TETRASIKLIN
}

\author{
Finnie Luthfia Suheri ${ }^{1}$, Zulkarnain Agus $^{2}$, Ivony Fitria ${ }^{3}$ \\ ${ }_{1}^{1}$ Faculty of Dentistry Andalas University \\ ${ }^{2}$ Faculty of Medicine Andalas University \\ ${ }^{3}$ Departemen of Dental Public Health Faculty of Dentristry Andalas University
}

\begin{abstract}
Staphylococcus aureus is one of the normal flora in the oral cavity, but these bacteria can change to be pathogen if there are predisposing factors such as changes in quantities of bacteria and decreasing of the immune response of the body. One of the ways to prevent is to inhibit the activity of these bacteria using antibiotics. Ampicillin and tetracycline are the broad-spectrum antibiotics that can inhibit the growth of positive and negative gram bacteria. This research was a laboratory experimental with Kirby-Bauer method and using CLSI standard. Total sample are 16 discs of ampicillin and 16 discs of tetracycline then placed on MHA media contain Staphylococcus aureus to see the inhibition power. The result showed that the averages of inhibition zone of ampicillin is 36,64 $\mathrm{mm}$ while tetracycline is $25,58 \mathrm{~mm}$. Independent sample $t$ test showed that $p<0,01$ which means there is a significantly difference between ampicillin and tetracycline. Ampicillin and tetracycline can inhibit the growth of Staphylococcus aureus with sensitive categories. Ampicillin is more sensitive and effective than tetracycline to inhibit the growth of Staphylococcus aureus Keywords : Ampicillin, Tetracycline, Staphylococcus aureus, Resistan
\end{abstract}

Affiliasi penulis : 1. Fakultas Kedokteran Gigi Universitas Andalas, 2. Fakultas Kedokteran Universitas Andalas

Korespondensi : Finnie Luthfia Suheri, email: finnieluthfia@yahoo.com, Telp: 082169727333

\section{PENDAHULUAN}

Penyakit gigi dan mulut merupakan penyakit tertinggi dan termahal ke-4 dalam pengobatan menurut The World Oral Health Report tahun 2008. ${ }^{1}$ Berdasarkan data RISKESDAS pada tahun 2007, didapatkan bahwa prevalensi penduduk provinsi Sumatera Barat yang mempunyai penyakit gigi dan mulut adalah sekitar $21,6 \%$ dan berdasarkan data RISKESDAS tahun 2013, prevalensi penyakit gigi dan mulut
Nasional adalah sekitar $25,9 \% .^{2}$ Ada dua penyakit gigi dan mulut yang mempunyai prevalensi cukup tinggi di Indonesia yaitu karies dan penyakit periodontal. ${ }^{3}$ Kedua penyakit tersebut diawali dengan terbentuknya biofilm di dalam rongga mulut atau yang dikenal dengan istilah biofilm oral. ${ }^{1}$ Bakteri biofilm adalah flora normal rongga mulut yang terdiri dari berbagai jenis mikroorganisme yang saling berhubungan satu sama lain dan merupakan suatu substrat yang solid berupa matriks eksopolimer. ${ }^{4} \mathrm{Di}$ dalam rongga mulut, terdapat multispesies bakteri biofilm yang tidak hanya 
berhubungan dengan pembentukan plak gigi dan karies tetapi juga dapat menyebabkan infeksi pada jaringan lunak dan jaringan periodontal. ${ }^{4}$

Rongga mulut manusia kaya akan mikroorganisme, di antaranya yaitu Staphylococcus epidermidis, Staphylococcus aureus, dan beberapa mikrokokus berpigmen yang tergolong mikroflora normal. Mikroflora normal ialah organisme yang umum ditemukan secara alamiah pada orang sehat dan hidup dalam hubungan yang seimbang dengan host. ${ }^{5}$ Mikroflora tersebut dapat dikatakan tidak menyebabkan penyakit dan mungkin menguntungkan bila berada di lokasi yang semestinya dan tanpa adanya keadaan abnormal, tetapi bila terdapat faktor predisposisi seperti perubahan kuantitasc mikroorganisme menjadi tidak seimbang dan penurunan daya tahan tubuh host, maka mikroflora normal dapat menyebabkan penyakit. ${ }^{5}$ Staphylococcus aureus merupakan salah satu mikroflora normal di rongga mulut, tetapi bisa bersifat patogen dan menimbulkan infeksi jika dipengaruhi faktor predisposisi seperti di atas., ${ }^{5,6}$ Infeksi yang disebabkan oleh bakteri ini biasanya timbul dengan tanda-tanda khas seperti peradangan, nekrosis, dan pembentukan abses. Beberapa penyakit dalam rongga mulut yang dapat disebabkan oleh bakteri ini yaitu abses, gingivitis, angular cheilitis, dan denture stomatitis. ${ }^{5,7,8,9}$

\section{Perkembangan metode} pencegahan terhadap infeksi di rongga mulut tergantung pada etiologi dari infeksi itu sendiri. Salah satu cara untuk mencegahnya yaitu dengan menghambat aktivitas bakteri rongga mulut tersebut. ${ }^{4}$ Untuk mengendalikan aktivitas bakteri tersebut, dapat dilakukan dengan menggunakan bahan antimikroba yaitu antibiotik. Pada saat ini, telah banyak digunakan berbagai jenis antibiotik. Beberapa penyakit infeksi dapat ditanggulangi dengan penggunaan antibiotik yang rasional, tepat, dan aman.

Antibiotik harus diberikan dalam dosis yang tepat dan penetrasi yang tepat dimana lokasi bakteri itu berada untuk dapat mengontrol populasi bakteri tersebut. ${ }^{10}$ Antimikroba adalah obat yang digunakan untuk memberantas infeksi mikroba pada manusia, sedangkan antibiotik adalah zat yang dihasilkan oleh mikroorganisme atau dihasilkan secara sintetik yang dapat membunuh atau menghambat perkembangan mikrorganisme. Antibiotik pertama kali ditemukan oleh Paul Ehlrich pada tahun 1910 dan masih menjadi obat andalan dalam penanganan kasus-kasus infeksi.10 
Pemakaiannya selama 5 dekade terakhir mengalami peningkatan yang luar biasa dimana hal ini tidak hanya terjadi di Indonesia tetapi juga di nega ra maju seperti Amerika Serikat. Antibiotik yang digunakan secara tepat dapat memberikan manfaat yang tidak perlu diragukan lagi, tetapi apabila dipakai atau diresepkan secara tidak tepat (irrational prescribing) dapat menimbulkan kerugian yang luas dari segi kesehatan, ekonomi, bahkan untuk generasi mendatang. ${ }^{10,11}$

Secara garis besar antimikroba dibagi menjadi dua jenis yaitu antimikroba yang membunuh bakteri (bakterisid) dan yang hanya menghambat pertumbuhan bakteri (bakteriostatik). ${ }^{12}$ Berdasarkan senyawa kimianya, antibiotik dibagi menjadi beberapa golongan, diantaranya yaitu Golongan Beta Laktam, Aminoglikosida, Makrolida, Tetrasiklin, Kloramfenikol, dan Sulfonamida. ${ }^{13,14}$

Antibiotik golongan Beta Laktam ( $\beta$-Lactam) dan golongan Tetrasiklin merupakan jenis antibiotik yang banyak dipilih karena pada umumnya infeksi di rongga mulut bersifat infeksi campur baik bakteri Gram positif dan Gram negatif, maupun bakteri aerob dan anaerob. Antibiotik ampisilin pada golongan Beta Laktam ( $\beta$ - Lactam) dan tetrasiklin pada golongan Tetrasiklin dapat dijadikan obat pilihan untuk kasus infeksi di rongga mulut, salah satunya penyakit infeksi yang disebabkan oleh bakteri Gram positif Staphylococcus aureus. 4

Berdasarkan hasil penelitian pola kepekaan bakteri Staphylococcus aureus terhadap antibiotik ampisilin di Provinsi Lampung tahun 2008-2012, didapatkan data bahwa bakteri Staphylococcus aureus yang sensitif mengalami penurunan dari tahun ke tahun dengan penurunan terendah pada tahun 2011 dengan persentase 9,8\%. Pada tahun 2012, tingkat resistensi Staphylococcus aureus yang sensitif mengalami kenaikan dengan persentase 22,8\%. ${ }^{15}$ Berdasarkan hasil penelitian pola kepekaan bakteri Staphylococcus aureus terhadap antibiotik tetrasiklin yang dilakukan di Laboratorium Mikrobiologi Klinik Fakultas Kedokteran Universitas Indonesia pada tahun 2001-2006, didapatkan data bahwa bakteri Staphylococcus aureus yang resisten cukup rendah yaitu dengan persentase $5,9 \%{ }^{16}$

Berdasarkan hasil survey pendahuluan, antibiotik yang masih dipakai di beberapa Puskesmas di Kota Padang adalah antibiotik amoksisilin, linkomisin, gentamisin, metronidazole, dll. Terdapat dua jenis antibiotik yaitu 
ampisilin dan tetrasiklin yang sudah tidak dipergunakan lagi perihal resistensinya. Agar pengobatan dapat berhasil, maka perlu dilakukan uji resistensi bakteri terhadap obat antibiotik oleh peneliti. ${ }^{17}$ Oleh karena itu, dalam skripsi ini, peneliti ingin mengetahui perbandingan uji resistensi bakteri Staphylococcus aureus terhadap obat antibiotik ampisilin pada golongan Beta Laktam ( $\beta$ - Lactam) dengan obat antibiotik tetrasiklin pada golongan tetrasiklin. Penelitian ini dilakukan di Laboratorium RSUP. Dr. M. Djamil Padang. RSUP. Dr. M. Djamil Padang merupakan rumah sakit umum tipe B pendidikan dan sebagai rumah sakit rujukan bagi rumah sakit tipe $\mathrm{C}$ dengan cakupan wilayah kerja Sumatera Barat, Riau, Jambi, dan Sumatera Utara bagian Selatan dimana rumah sakit umum ini memiliki fasilitas Laboratorium yang lengkap dan modern.

\section{METODE}

Jenis penelitian yang dilakukan adalah eksperimental laboratorium. Besar sampel dalam penelitian ini dihitung menggunakan rumus Frederer dan didapatkan hasil bahwa jumlah perlakuan (t) yang dipakai adalah 2, artinya pada kedua kelompok dilakukan sebanyak 16 kali percobaan. Tujuan penelitian ini adalah untuk mengetahui perbandingan uji resistensi dua jenis antibiotik yang memiliki golongan berbeda berdasarkan senyawa kimianya yaitu antibiotik ampisilin pada golongan Beta aktam ( $\beta$ Lactam) dan antibiotik tetrasiklin pada golongan Tetrasiklin dengan menghitung zona hambat kedua antibiotik tersebut terhadap pertumbuhan bakteri Staphylococcus aureus.

Metode yang digunakan dalam penelitian ini adalah metode Kirby-Bauer (Filter Paper Disk Agar Diffusion Method) dan menggunakan standar CLSI (Clinical Laboratory Standards Institute). Penelitian dilakukan dengan menggunakan disk antibiotik ampisilin $10 \mu \mathrm{g}$ dan disk antibiotik tetrasiklin $30 \mu \mathrm{g}$. Sebanyak 1-2 ose dari biakan bakteri uji yang telah dikultur dan tumbuh disuspensikan dengan menggunakan $\mathrm{NaCl}$ 0,9\% sampai diperoleh kekeruhan yang sama dengan standard Mc.Farland 0,5 . Setelah itu disiapkan cawan petri berisi Mueller Hinton Agar yang akan digunakan sebagai media uji bakteri. Staphylococcus aureus yang telah disuspensi diambil dengan menggunakan cotton bud steril dan digoreskan secara merata ke seluruh permukaan cawan petri yang berisi Mueller Hinton Agar. Kemudian cakram antibiotik ampisilin dan antibiotik tetrasiklin diletakkan disetiap area pada cawan petri. Setelah itu cawan petri diinkubasi di dalam 
inkubator pada suhu 37o C selama 24 jam. Setelah 24 jam, cawan-cawan petri tersebut dikeluarkan dari inkubator dan dilihat daya hambat yang terjadi pada setiap cakram dan diukur zona bening yang terbentuk dengan menggunakan kaliper.

\section{HASIL}

Setelah diamati pada masingmasing cakram, hasil inkubasi media uji bakteri menunjukkan adanya daya hambat yang dihasilkan oleh cakram antibiotik ampisilin $10 \mu \mathrm{g}$ dan cakram antibiotik tetrasiklin $30 \mu \mathrm{g}$ terhadap pertumbuhan bakteri Staphylococcus aureus.

Tabel 1. Rata-rata diameter zona hambat kelompok Perlakuan

\begin{tabular}{cccc}
\hline $\begin{array}{l}\text { Kelompok } \\
\text { perlakuan }\end{array}$ & $\mathrm{n}$ & $\begin{array}{l}\text { Mean } \\
(\mathrm{mm})\end{array}$ & $\begin{array}{l}\text { Standar } \\
\text { Deviasi }\end{array}$ \\
\hline Ampisilin & 16 & 36,64 & 1,09197 \\
Tetrasiklin & 16 & 25,58 & 1,00544 \\
\hline
\end{tabular}

Uji statistik yang digunakan pada penelitian ini menggunakan uji normalitas yaitu uji Shapiro-Wilk. Hasil menunjukkan data terdistribusi normal, maka dilanjutkan dengan uji Independent Sample T-test untuk melihat perbedaan pada kedua kelompok perlakuan.

Uji Independent Sample T-test menunjukkan nilai $\mathrm{p}=0,000 \quad(\mathrm{p}<0,01)$ yang artinya bahwa uji resistensi antibiotik ampisilin dan antibiotik tetrasiklin memberikan efek antibakteri yang sangat signifikan dan terlihat perbedaan yang bermakna dalam menghambat pertumbuhan bakteri Staphylococcus aureus.

\section{PEMBAHASAN}

Pada penelitian ini, menunjukkan adanya daya hambat yang dihasilkan oleh antibiotik ampisilin dan antibiotik tetrasiklin terhadap pertumbuhan bakteri Staphylococcus aureus. Kedua jenis antibiotik tersebut memiliki kategori tingkat resistensi yang sensitif, tetapi antibiotik ampisilin memiliki daya hambat yang lebih efektif dibandingkan dengan antibiotik tetrasiklin yang dibuktikan dengan diameter zona bening di sekitar cakram antibiotik ampisilin yang lebih besar dibandingkan dengan antibiotik tetrasiklin. Pengulangan yang dilakukan sebanyak $16 \quad$ kali memperlihatkan rata-rata zona hambat antibiotik ampisilin adalah 36,64 $\mathrm{mm}$ dengan diameter terbesar adalah 37,85 mm dan diameter terkecil adalah 34,6 $\mathrm{mm}$. Antibiotik tetrasiklin memiliki ratarata zona hambat yaitu 25,58 $\mathrm{mm}$ dengan diameter terbesar adalah 27,4 $\mathrm{mm}$ dan diameter terkecil adalah $23,85 \mathrm{~mm}$.

Zona hambat yang terbentuk di sekeliling cakram memiliki ukuran diameter yang bervariasi. Hal ini dapat disebabkan oleh beberapa faktor, yaitu 
diantaranya goresan bakteri uji yang tidak merata pada media uji, sehingga ada bagian dari media Mueller Hinton Agar (MHA) yang jumlah bakteri tumbuhnya tidak sama dengan bagian-bagian lainnya dan dapat juga dikarenakan penggoresan bakteri uji yang sudah merata, namun tidak tumbuh dengan sempurna, sehingga tidak terjadi efek antibakteri di sekeliling cakram tersebut.

Tingkat resistensi bakteri terhadap antibiotik menurut standar penilaian diameter zona hambat antibiotik berdasarkan CLSI (Clinical Laboratory Standards Institute) dikelompokkan menjadi tiga kategori yaitu sensitif, intermediet, dan resisten. Suatu bakteri dikatakan sensitif terhadap antibiotik apabila bakteri tersebut dapat dihambat dengan baik dan terbentuk zona bening pada saat diuji (peka terhadap antibiotik), kategori intermediet apabila bakteri dapat dihambat tetapi dengan daya hambat yang lebih lemah, dan kategori resisten apabila bakteri dapat dihambat tetapi menunjukkan daya hambat yang sangat lemah atau tidak terbentuk daya hambat sama sekali.

\section{Berdasarkan CLSI (Clinical}

Laboratory Standards Institute), untuk antibiotik ampisilin tingkat resistensi dikategorikan sensitif apabila diameter zona hambat bakteri $\geq 17 \mathrm{~mm}$, kategori intermediet apabila diameter zona hambat bakteri 14-16 mm, dan kategori resisten apabila diameter zona hambat bakteri yaitu $\leq 13 \mathrm{~mm}$. Tingkat resistensi antibiotik tetrasiklin dikategorikan sensitif apabila diameter zona hambat bakteri $\geq 19 \mathrm{~mm}$, kategori intermediet apabila diameter zona hambat bakteri 15$18 \mathrm{~mm}$, dan kategori resisten apabila diameter zona hambat bakteri $\leq 14 \mathrm{~mm}$. Berdasarkan penjelasan tersebut, efek antibakteri antibiotik ampisilin dan antibiotik tetrasiklin memiliki tingkat resistensi dengan kategori sensitif tetapi ratarata diameter zona hambat pada antibiotik ampisilin lebih besar dari antibiotik tetrasiklin.

Hasil uji Independent Sample Ttest menunjukkan nilai $\mathrm{p}=0,000$ yang berarti terdapat pengaruh yang sangat signifikan yang diberikan antibiotik ampisilin dan antibiotik tetrasiklin terhadap pertumbuhan bakteri Staphylococcus aureus. Hal ini dapat disebabkan karena kedua antibiotik ini merupakan antibiotik berspektrum luas yang dapat menghambat pertumbuhan baik bakteri Gram positif dan Gram negatif, maupun bakteri aerob dan anaerob.

Antibiotik ampisilin dan antibiotik tetrasiklin merupakan dua jenis antibiotik yang memiliki golongan yang 
berbeda. Antibiotik ampisilin merupakan jenis antibiotik golongan Beta Laktam $(\beta$ Lactam) yang mempunyai mekanisme kerja yaitu dengan menghambat sintesis dinding sel bakteri dengan cara mengikat satu atau lebih pada ikatan penisilinprotein (Protein Binding Penisilin), sehingga menyebabkan penghambatan pada tahapan akhir transpeptidase sintesis peptidoglikan dalam dinding sel bakteri yang mengakibatkan biosintesis dinding sel terhambat dan sel bakteri menjadi pecah (lisis). Sintesis dinding sel yang terganggu mengakibatkan bakteri tersebut tidak mampu mengatasi perbedaan tekanan osmosa di luar dan di dalam sel yang mengakibatkan bakteri mati. ${ }^{18}$ Pada penelitian yang dilakukan oleh Slamet Djais pada tahun 2012 tentang antibiotik ampisilin pada pencabutan gigi dalam kerja sosial di Lampung, antibiotik ampisilin memiliki tingkat resistensi sensitif dengan persentase $76-82,6 \%$ terhadap bakteri Staphylococcus aureus sebagai penyebab radang gigi atau infeksi di rongga mulut. Antibiotik ampisilin sering digunakan dan menjadi pilihan di dalam pengobatan karena lebih aman dan berkhasiat terapi pada dosis yang telah ditetapkan. $^{19}$

Antibiotik tetrasiklin merupakan salah satu antibiotik berspektrum luas yang memiliki mekanisme kerja dengan menghambat sintesis protein bakteri pada ribosomnya. Antibiotik berikatan secara reversibel dengan ribosom $30 \mathrm{~s}$ dan mencegah ikatan tRNA-aminoasil pada kompleks mRNA ribosom. Hal tersebut mencegah perpanjangan rantai peptida yang sedang tumbuh dan berakibat terhentinya sintesis protein. ${ }^{18}$

Pada penelitian yang dilakukan oleh Yetty Herdiati tahun 2012 tentang antibiotik tetrasiklin sebagai salah satu antibiotik yang dapat menghambat pertumbuhan Staphylococcus aureus, didapatkan hasil uji antibiotik tetrasiklin terhadap pertumbuhan bakteri Staphylococcus aureus dengan kategori sensitif yaitu dengan rata-rata zona hambat $21 \mathrm{~mm} .20$

Perbedaan hasil persentase dan hasil uji resistensi bakteri terhadap antibiotik pada penelitianpenelitian sebelumnya terjadi karena banyak faktor yang mempengaruhi. Resistensi bakteri terhadap antibiotik bisa diakibatkan dari pemakaian antibiotik dalam jangka waktu yang relatif lama dan terus menerus, sehingga memungkinkan bakteri tersebut mengenal cara kerja antibiotik tersebut dan dapat membentuk mekanisme pertahanan diri apabila nantinya diserang oleh antibiotik yang sama. ${ }^{21}$ Antibiotik dapat kembali sensitif dikarenakan penggunaannya yang baru atau jarang 
digunakan dalam pengobatan, sehingga bakteri tersebut memerlukan waktu yang lama untuk membuat mekanisme pertahanan terhadap antibiotik. Faktor kepatuhan dari diri pasien dapat mempengaruhi terjadinya resistensi antibiotik, jika pasien tidak memiliki kepatuhan dalam mengkonsumsi antibiotik dengan benar maka dapat memicu dan mempercepat terjadinya bakteri resisten terhadap antibiotik. ${ }^{21}$

\section{KESIMPULAN}

Obat antibiotik ampisilin pada Golongan Beta Laktam ( $\beta$-Lactam) dan antibiotik tetrasiklin pada Golongan Tetrasiklin memiliki daya hambat terhadap\pertumbuhan bakteri Staphylococcus aureus dengan kategori tingkat resistensi sensitif. Obat antibiotik ampisilin lebih sensitif dan lebih efektif dibandingkan dengan obat antibiotik tetrasiklin dalam menghambat pertumbuhan bakteri Staphylococcus aureus.

\section{KEPUSTAKAAN}

1. Prismasari, dkk. 2010. Literature Review: Potential Use of Cinnamomum Burmanii Essential Oil-Based Chewing Gum as Oral Antibiofilm Agent. Journal of Dentistry Indonesia 2010; Vol. 17 No. 3, 80-86.

2. Departemen Kesehatan RI. 2013. Laporan Hasil Riset Kesehatan Dasar (RISKESDAS) Nasional. Badan Penelitian dan Pengembangan Kesehatan Dasar Depkes RI. Jakarta.

3. Suwondo, Syarif. 2007. Skrining Tumbuhan Obat yang Mempunyai Aktivitas Antibakteri Penyebab Karies
Gigi dan Pembentukan Plak (Screening of Medicinal Plant on Antimicrobial Caused Caries and Plaque Forming Activity). Jurnal Bahan Alam Indonesia ISSN 14122855; Vol. 6, No. 2.

4. Brotosoetarno, Sunarso dan Yani Corvianindya R. 2004. Resistensi Bakteri Oral Biofilm Terhadap Antibiotika Golongan Beta- Laktam. Indonesian Journal of Dentistry 2004; 11(2): 83-87.

5. Syahrurachman, dkk. 2010. Buku Ajar Mikrobiologi Kedokteran. Jakarta : Binarupa Aksara Publishers 2010.

6. Archer, N.K. 2011. Staphylococcus aureus Biofilms Properties, Regulation, and Roles in Human Disease. Landes Bioscience. Virulence 2:5, 445-449.

7. Azadeh M, dkk. 2011. The Profil of Pathogenic Isolated from Dental PlaqueIndeuced Gingivitis. International Journal of Molecular and Clinical Microbiology 2011;p. 36-9.

8. Smith A, dkk. 2003. Staphylococcus Aureus in the Oral Cavity: a three-year Retrospective Analysis of Clinical Laboratory Data. British Dental Journal 2003; 195(12):p. 701-3.

9. Jackson MS. 2011. The Ecology of Staphylococcus Species in the Oral Cavity. J Med Microbiol 2011; 50(11): p. 940-6.

10. Utami, Eka. 2012. Antibiotika, Resistensi, dan Rasionalitas Terapi. Journal of Sainstis 2012; Vol. 1 No. 1.

11. Zhang, Y. 2007. Mechanisms of Antibiotic Resistance in the Microbial World. Baltimore, USA.

12. Wulandari, Erni. 2012. Kepekaan Pasteurella multocida yang Diisolasi dari Sapi yang Berasal dari Kabupaten Aceh Barat Terhadap Beberapa Antibiotik. Jurnal Medika Veterinaria ISSN 08531943; 95-97.

13. Gould I.M. 2009. Antibiotic Resistance: The Perfect Storm. International Journal of Antimicrobial Agents 2009; S2-S5.

14. Arnold, Edward. 2010. A Clinical Review of Antibacterial, Antifungal, Antiparasitic, and Antiviral Drugs. Kucer's The Use of Antibiotics Journal 2010; Vol. 1.

15. Muttaqein, EZ. 2013. Pattern Sensitivity of Staphylococcus aureus to Antibiotic Penicilin Period of Year 2008-2013 in Bandar Lampung. ISSN 2337-3776. 
16. Tommy, P. 2007. Pola Resistensi Bakteri dalam Darah Terhadap Kloramfenikol, Trimethoprim/Sulfametoksazol, dan Tetrasiklin di Laboratorium Mikrobiologi Klinik Universitas Indonesia (LMK FK UI) pada Tahun 2001-2006. Perpustakaan Universitas Indonesia. [Cited 23/01/2015); available from: http://lib.ui.ac.id/opac/ui/detail.jsp?id=122 $\underline{650}$ \&lokasi=lokal.

17. Bhaskara, Bagus. 2012. Uji Kepekaan Escherichia coli Sebagai Penyebab Kolibasilosis Pada Babi Muda Terhadap Antibiotik Oksitetrasiklin, Streptomisin, Kanamisin, dan Gentamisin. Jurnal Indonesia Medicus Veterinus ISSN 2301 